\title{
Improving policy implementation through collaborative policymaking
}

Ansell, Christopher; Sørensen, Eva; Torfing, Jacob

Published in:

Policy and Politics

DOI:

$10.1332 / 030557317 \times 14972799760260$

Publication date:

2017

Document Version

Peer reviewed version

Citation for published version (APA):

Ansell, C., Sørensen, E., \& Torfing, J. (2017). Improving policy implementation through collaborative policymaking. Policy and Politics, 45(3), 467-486. https://doi.org/10.1332/030557317X14972799760260

\section{General rights}

Copyright and moral rights for the publications made accessible in the public portal are retained by the authors and/or other copyright owners and it is a condition of accessing publications that users recognise and abide by the legal requirements associated with these rights.

- Users may download and print one copy of any publication from the public portal for the purpose of private study or research.

- You may not further distribute the material or use it for any profit-making activity or commercial gain.

- You may freely distribute the URL identifying the publication in the public portal.

Take down policy

If you believe that this document breaches copyright please contact rucforsk@kb.dk providing details, and we will remove access to the work immediately and investigate your claim. 


\title{
Improving Policy Implementation through Collaborative Policymaking
}

\author{
Abstract: \\ We offer a fresh and synthesizing perspective on policy execution problems by suggesting that \\ collaborative policy design and adaptive policy implementation will help public policy makers to \\ prevent implementation problems and improve policy execution. Classical implementation theories \\ have focused too narrowly on administrative stumbling blocks and New Public Management has \\ reinforced the implicit, but unfortunate split between politics and administration. Attempts to \\ improve policy execution must necessarily begin by looking at policy design, which can be \\ improved through collaboration and deliberation between upstream and downstream actors, \\ including the potential service users and other non-governmental actors. We provide a broad \\ overview of how collaborative policymaking and adaptive policy implementation might work in \\ theory and practice.
}

\section{Introduction}

Although many laws and government programs are successfully implemented, the failure to turn public policies into practice and deliver the intended outputs and outcomes is common (Hall, 1982; Volcker, 2014; Light, 2015). The discovery and explanation of implementation failures is a fundamental achievement of modern political science. Classical political scientists readily assumed that public policies, defined as courses of action and inaction, regulatory measures, social welfare programs, and funding priorities promulgated by democratically elected governments, would be smoothly implemented by efficient public bureaucracies and eventually solve the problems they were meant to solve. However, public administration scholars have shown that implementation 
cannot be taken for granted and that implementation problems undermine elected politicians' capacity to govern society and the economy.

Today, there is a renewed focus on implementation failure, defined as the emergence of a significant gap between the planned outputs and outcomes of public policy and what actually occurs. Implementation problems such as low take-up, poor quality, budget transgressions and the failure to meet stated objectives and achieve desired results and effects seem to be more and more prevalent. The new managerialist discourse has reframed implementation problems as 'policy execution problems', and a survey from 2008 shows that 49 percent of a representative sample of public leaders in the US deem government to be less capable of executing policies than 10 years ago (Deloitte Research, 2008). This evidence is corroborated by new research that reveals that the number of federal government policy breakdowns rose from 1.6 per year in period 1986-2001 to 3.3 per year in the period 2001-2015 (Light, 2015). The decline in policy execution capacity can be explained partly by the growing complexity of society and partly as the result of public leadership problems and administrative constraints. However, although we may have more implementation failures than before, we should not forget that the growing emphasis on performance measurement makes implementation problems easier to spot (Macmillan and Cain, 2012).

A number of implementation scholars have suggested that improving policy design, connecting policy designers with front-line staff and target groups, and enhancing the flexible choice of policy instruments are important for avoiding implementation failure (Hoppe, van de Graaf, and van Dijk, 1987; Linder and Peters, 1987; Ingram and Schneider, 1990; May, 2012; Howlett, 2014). Building on and synthesizing and extending these suggestions, we aim to offer a more comprehensive perspective on policy implementation problems, arguing that collaborative policy design and 
adaptive policy implementation will help public policymakers ensure successful policy execution. To this end we advance a series of interconnected claims:

The first claim is that policy execution problems require joint consideration of both policy design and policy implementation. Although it has been demonstrated that the politics-administration dichotomy does not hold up in practice (Hill and Hupe, 2014), the focus of classical implementation theories on administrative stumbling blocks to policy implementation tended to reproduce this dichotomy (Meier and Bohte, 2007). As a result, the classical theories gloss over the fact that policy designs - defined here as deliberate attempts to craft a comprehensive set of visions, goals, causal assumptions, rules, tools, strategies and organizations to address a particular policy problem (Linder and Peters, 1987; Ingram and Schneider, 1990; May, 2012) - are often flawed and illconceived, making them difficult to implement and preventing them from solving the problem.

The second claim is that New Public Management (NPM) builds on and reinforces the classical Weberian and Wilsonian politics-administration divide (Box, 1999). NPM aims to solve the implementation problems identified by the classical implementation theories, but in so doing it invokes a principal-agent logic that reinforces the separation between policy design and policy execution. The failure to address issues pertaining to policy design marks the limits of NPM.

The third claim is that the strict separation of policy design and policy execution must be relaxed in both theory and practice. Attempts to improve policy execution must necessarily begin by looking at policy design, not only in order to anticipate future implementation problems, but also to create policies that work on the ground and deliver desired results because they carefully align problems, solutions, interests and organizational resources (Linders and Peters, 1987). 
The fourth claim is that policy designs can be improved through collaboration and deliberation between upstream and downstream actors, including the potential service users and other nongovernmental actors, and that this will blur the lines allegedly separating politics and administration (Hoppe, van de Graaf, and van Dijk, 1987). Multi-actor collaboration through joint deliberations will not only help to convey valuable knowledge about the nature and character of the problem and the kinds of solutions likely to work on the ground. It will also spur the development of innovative policy solutions that can break policy deadlocks and build joint ownership for the realization of these solutions.

The fifth claim is that policy design must be conceived of as an on-going process that flexibly adapts as implementation challenges unfold (Berman, 1980; see also Majone and Wildavsky, 1979). The implementation of policy designs shaped through processes of collaborative innovation cannot be ensured through programmatic processes based on command and control, but requires a continued collaboration that ensures flexible adaption of policy strategies to local conditions and emerging constraints through processes of mutual learning and practical experimentation. The emphasis on adaptive implementation further blurs the lines separating politics from administration.

The sixth claim is that the obstacles to elected politicians' participation in collaborative policymaking are real, but can be overcome. It is at best challenging to motivate politicians from elected assemblies and offices to sponsor and participate in collaborative policy design and adaptive policy implementation. However, although politicians will be reluctant to embrace the idea of collaborative policymaking, there are several factors supporting a cautious, and perhaps increasing, embrace. 
The final claim is that the potential benefits of collaborative policymaking for improving policy execution warrants a closer examination of the scope conditions of policymaking that allow us to appreciate where, when and how collaborative policymaking is possible.

The article is structured around our attempts to validate these claims that together offer a new approach to implementation analysis, which both presupposes and entails a theoretical rapprochement between the different generations of implementation theory (deLeon and deLeon, 2002) and new theories of collaborative governance (Ansell and Gash, 2008; Emerson, Nabatchi, and Balogh, 2012) and collaborative innovation (Bommert, 2010; Hartley, Sørensen and Torfing, 2013).

\section{Limits of Classical Implementation Theory}

From the 1970s onwards there has been an increasing focus on the gap between design and execution of public policy and the need to close it. The optimistic interventionist belief in social engineering through rational policymaking followed by bureaucratic implementation was shattered by reports documenting the failure to implement well-intended public policies. Despite the growing attention to implementation problems, they are still with us. The implementation of the Patient Protection and Affordable Care Act in the USA is a case in point as there are several examples of mismatch between its stated intentions and the actual results (May, 2015). Problems with ensuring policy execution can be found in all countries and at all levels of government and give rise to considerable frustration among government officials, public managers and citizens. In times of dire fiscal constraint, the failure of new, expensive policy programs to deliver the expected results gives rise to mediatized blame-games that undermine the trust in government (Hood, 2010). 
There are three classical explanations of implementation failure. First, the top-down explanation famously advanced by Pressman and Wildavsky (1973) looks at how public policies formulated by political decisionmakers are communicated to lower level public administrators who are responsible for their implementation. Policymakers are connected to local delivery agencies through long implementation chains with numerous veto points. At each of these veto points, imprecise goals, political conflicts, competing obligations, the complexity of joint action, or the lack of resources, skills and commitment can cause deviations that significantly lower the chance of successful implementation and enhance the risk of failure. The longer the implementation chains are, the higher the risk of failure.

Second, the bottom-up explanation advocated by Lipsky (1980) claims that the top-downers have overlooked the significance of the bottom-level of the implementation chain. Here we find the street-level bureaucrats with direct interaction with service users and a considerable degree of discretion in their work. Although street-level bureaucrats act on behalf of political principals, their work is not regulated in great detail and is difficult to monitor. This means that they play a critical role in defining the goals governing their efforts and in choosing the tools for meeting these goals. The latitude of choice enjoyed by street-level bureaucrats is exercised within legal bounds, but they have enough leeway to significantly influence the implementation of public policies. Street-level bureaucrats are caught in a cross-fire between, on the one hand, the often contradictory demands from legislation, professional norms and target users and, on the other hand, the limited time and resources that they have at their disposal. In order to deal with these constant pressures and create a tolerable working situation, they develop administrative coping strategies that, for example, involve reduction of the demand for services, rationing of services, routinization and automation of service 
delivery and attempts to control the users and citizens they are serving. Depending on how successful they are in developing such coping strategies, the discretionary practices of street-level bureaucrats will distort the production and delivery of services and prevent the realization of the overall policy objectives. This will eventually lead to policy execution failure.

Thirdly, the outside-in explanation argues that implementation problems may also be caused by unintended and unforeseen behavior of target groups and private stakeholders. The traditional chain of government assumes that citizens and service users will readily comply with rules and legislation and respond to sanctions and incentives provided by public policies. However, some target users, and the organizations representing and defending their interests, may obstruct the implementation of new policies by putting up an active and direct resistance, refusing to comply with particular rules and regulations, playing games with the system, or acting in a non-cooperative and disengaged manner in relation to regulators and service providers (Braithwaite, 1995). Even if the target groups comply with the official requirements, there is no guarantee that public policies succeed to eliminate the policy problem since it may be produced by socioeconomic subsystems that are selfreferential and driven by internal dynamics that are almost impossible to influence through centralized political and juridical control (Teubner and Willke, 1984; Mayntz, 1993). These outside-in explanations take us beyond the discretionary action of street-level bureaucrats and locate the source of implementation failure in behavioral reactions and systemic logics outside the public sector.

Although there have been some controversy between the advocates of the three classical implementation theories, they seem perfectly compatible, and over the years some integrated models have emerged (see Sabatier, 1986; Matland, 1995). Weaver (2010) has recently presented 
an integrated framework in which classical top-down concerns with mission drift, organizational resistance, coordination issues, political interference and capacity problems are supplemented by concerns for program operator issues from bottom-up theory and target compliance issues from outside-in theory. Weaver's integrated framework is surely helpful in diagnosing sources of implementation failure, but it also reveals the limitation of the classical implementation theories since there is no mentioning of the implementation problems emanating from ill-conceived policy designs.

This benign omission is problematic since many policies fail because they are badly designed (Ingram and Schneider, 1990; Winter and Nielsen, 2008; May, 2015). Hence, public policies that are based on misunderstandings of the problem, insufficient knowledge of the context for its solution, vague and contradictory goals, a mismatch between means and ends, an incomplete strategy for execution, a weak story line and the lack of political and administrative support are prone to failure because they ill-conceived. If the policy design is flawed in terms of its form and substance, it has little importance whether the policy is communicated correctly down the implementation chain, program operators embrace its basic principles, and target users want to participate. Some policies appear to be 'crippled at birth' (Hogwood and Peters, 1985: 23), and as a result even 'the best public bureaucracies in the world would have no chance of making them successful' (Linders and Peters, 1987: 461).

The analysis of policy design is the blind spot of the classical implementation theories. As conveyed by Figure 1 below, the classical theories assume a clear-cut divide between politics and administration by locating the three main sources of failure in the administrative implementation process that runs from the top to the bottom of public bureaucracy and out to targets users and 
societal subsystems. They are narrowly focused on identifying and removing the administrative stumbling blocks and fail to consider that the real obstacle to policy execution may lie in badly designed policies.

Figure 1: $\quad$ Sources of implementation failure in classical implementation theories

[Please insert figure 1 about here]

\section{The attempt of NPM to solve the classical implementation problems}

The NPM reform program (Hood, 1991) that developed in the 1990s in the Anglo-Saxon countries and then spread to most of the Western world has explicitly aimed to solve the implementation problems diagnosed by the classical implementation theories. Let us briefly see how this was done.

Firstly, in his highly influential book Instructing to Deliver Barber (2008) claims that the policy execution problems identified by top-down implementation theorists can be solved by importing performance management techniques from private companies into the public sector. According to Barber, it is not enough for executive leaders in public service organizations to specify the goals and principles of public policies, no matter how clearly and forcefully they do so. In addition, they must ensure that people all the way down to the frontline have a correct understanding of these goals and principles and sufficient motivation and means to realize them in practice. Finally, top-level managers should have a clear 'line of sight' all the way from the top to the bottom of their organization so that they can identify and assess inputs, outputs and outcomes, evaluate overall performance, reward the good performers and punish the bad ones. This recipe is at the core of what Barber calls 'deliverology'. Policy execution problems can be cured if executive leaders clearly set out the goals 
and communicate the program theory, carefully plan the implementation process, and follow up by organizing regular stocktaking meetings and benchmarking the performance of all agencies.

Secondly, it is commonly believed by NPM advocates that policy execution problems caused by street-level bureaucrats pursuing alternative agendas can be cured by new forms of leadership and management. However, it is not sufficient for public managers to use sticks and carrots to persuade the professionally trained employees to perform well and meet the expected goals and standards. They should also seek to transform, or at least, influence the way that street-level bureaucrats perceive their goals and mission, their delegated tasks and their role in accomplishing these. Public managers must get into the heads of their employees in order to shape their visions, goals, values, perceptions and identity in ways that support policy implementation. In short, managers must supplement the traditional forms of transactional leadership based on a combination of instruction, correction and rewards with a new kind of charismatic and transformational leadership that aims to win the hearts and the minds of public employees and thus makes them embrace the policy mission and work hard to realize it (Kotter, 1999; Burns, 2003).

Last but not least, NPM implicitly asserts that the problems created by recalcitrant target groups can be cured by enhancing their ownership over new policy solutions through the creation of exit and voice mechanisms (Hirschman, 1970; Sørensen, 1997). Exit mechanisms that provide free choice of service provider will give users a more active role in service production by letting them vote with their feet. Voice options via user-satisfaction surveys and participation on user boards will give them a feeling of being able to shape the services they receive. Hence, treating citizens as customers empowered to make choices and express valued opinions tends to make them a part of the solution and therefore increases input legitimacy (Pierre and Røiseland, 2016). If this is not 
enough to ensure take-up or compliance with new policy solutions, public authorities can use different nudging techniques to influence user behavior (Halpern, 2015). The other problem identified by outside-in implementation theories is the failure of government to influence selfreferential subsystems. NPM aims to solve this problem by encouraging 'regulated self-regulation' of economic and social subsystems. Instead of trying to enforce compliance, a light-handed use of regulatory tools characterized as 'soft governance' may help to mobilize societal subsystems and take advantage of their capacity for self-regulation to achieve overall policy objectives (Sørensen and Triantafillou, 2009). The creation of 'resilient neighborhoods' and 'quasi-markets' is a good example of this.

The limits to NPM's three cures - performance management, charismatic and transformational leadership and mobilization of self-regulating systems - are discussed elsewhere (Parry and Bryman, 2006; Moynihan, 2008; Le Grand, 2011; Bartels, Cozzi and Mantovan, 2012). The point we want to make here is not that the recommendations of NPM are all wrong, but rather that they are insufficient because they fail to address the crucial issue of policy design. In fact, by relying on principal-agent logic that prescribes a strict separation between 'political steering' and 'administrative rowing' (Osborne and Gaebler, 1993), NPM is discouraged from discussing any matters pertaining to policy design. When the political principal has designed a policy, the only question left is how to ensure that the administrative agent delivers. In short, NPM exacerbates the problem found in classical implementation theory rather than solving it.

\section{4. 'It's the Policy Design, Stupid!'}

Some implementation theorists have already recognized the need for looking more closely at policy design (Linders and Peters, 1987; Ingram and Schneider, 1990; Winter and Nielsen, 2008; May, 
2012). Their argument is that many administrative implementation problems can be avoided if they are properly anticipated and dealt with in the policy design phase (Bobrow and Dzek, 1987; Schneider and Ingram, 1988, 1990; Weaver, 2010). However, we are not convinced that the argument about the anticipation of implementation problems is a particularly strong one. Not only is it difficult to foresee future problems and contingencies due to the existence of both 'known unknowns' and 'unknown unknowns' (Weaver, 2010: 10), but it is even more difficult to convince policymakers that they should pay attention to implementation problems in the midst of their efforts to negotiate and design new policies. As Weaver remarks: 'Legislators get political credit for legislation passed, not implementation problems avoided. Legislators also see implementation as "someone else's problem" rather than something that they should be concerned about' (Weaver, 2010: 11).

When we insist that implementation studies should pay more attention to policy design, it is first and foremost because substantive and political flaws in policy designs often prevent their implementation and the delivery of expected results (Comfort, 1980; Howlett, 2009, 2014). The flaws that undermine the execution of public policy cannot be attributed solely to cognitive constraints on policymakers (Simon, 1957) or the contingent coupling of different policy streams (Kingdon, 1984). Neither can these flaws be avoided by applying more scientific skill and analytical rigor when designing policies and being clearer when communicating the policy goals to the frontline (Goggin et al., 1990). The problem is rather that policy designs tend to suffer from the failure to properly deal with the substantive and inherently political issues involved in policymaking. When confronted with complex policy problems such as climate change mitigation, rising levels of unemployment and traffic congestion in inner cities, policy success depends on crafting innovative and yet feasible policies based on a careful definition and alignment of 
problems, goals, tools, strategies, and organizational platforms. However, the process of definition and alignment is fundamentally political rather than technocratic because the inherent value and interest conflicts, power games, legitimacy concerns and tradeoffs between equally desirable goals must be considered. Indeed, the criteria for judging public policy as successful are subject to intense political debates. Hence, as indicated in Figure 2, we claim that flawed policy design adds a fourth source of policy execution failure that is clearly located in the political rather than administrative realm.

\section{Figure 2: $\quad$ Four sources of policy execution failure}

[Please insert figure 2 about here]

There is no 'one best way' when it comes to designing public policies. There are many possible policy designs that deserve real-life testing, and the important thing is not to 'get the policy right' in a strictly rationalistic sense that requires full information and a problem diagnosis that precedes the choice of the optimal solution. What is important, though, is to ensure: 1) that the policy problem is scrutinized from multiple perspectives in order to avoid one-sided or simplistic understandings; 2) that goals, tools and strategies are defined and articulated as part of a plausible and empirically sustained change theory; 3) that the new policy design is innovative enough to break the obstructive trade-offs between different goals and constraints associated with wicked and unruly problems; 4) that key public and private stakeholders subscribe to the storyline that defines and brands the new policy; 5) that organizational and technological platforms support the strategic efforts to implement the policy; and 6) that the policy is sufficiently open and flexible to allow for subsequent adjustment. 
In order to meet these demands the political and administrative decisionmakers must engage in a pragmatic adjustment process in which they constantly move back and forth between preliminary problem definitions, bold but provisional change theories, innovative solutions, competing narratives and storylines, and contingent organizational and technological designs. This complex political alignment process defies description based on linear decisionmaking models and necessitates collaboration between upstream and downstream actors as well as between public and private stakeholders, including target groups and their representative organizations.

\section{Improving Policy Execution through Collaborative Policy Design}

While classical implementation theories focused their attention on the administrative obstacles to policy execution, some recent contributions to implementation studies suggest that we pay more attention to policy design (Hoppe, van de Graaf, and van Dijk, 1987; Linder and Peters, 1987; Ingram and Schneider, 1990; May, 2012). However, these contributions have primarily focused on the political and administrative decisionmakers and how they can anticipate implementation problems in their selection of policy instruments (Howlett, 2009, 2014). Our argument is that to improve policy execution we must go one step further and consider how policies can be more effectively designed by connecting actors vertically and horizontally in a process of collaboration and joint deliberation.

Policy design often takes place in a highly politicized context with many conflicts and strong time pressures. Therefore, collaboration should not be equated with a long and cumbersome search for unanimous consent on the basis of what Habermas (1987) has termed 'communicative rationality', but rather be defined as a shared effort to establish a common ground for public problem solving 
through a constructive management of difference that leaves room for dissent and grievance (Gray, 1989). As such, collaboration aims to harness difference without eliminating it.

The idea that multi-actor collaboration can enhance policy implementation is not entirely new. Bottom-up implementation theorists have long insisted that street-level bureaucrats and target users have important skills and resources and possess a practical knowledge that can help policymakers and executive managers to better understand the problem and the context for its solution. Elmore writes: 'Unless the initiators of a policy can galvanize the energy, attention and skills of those affected by it, thereby bringing these resources into a loosely structured bargaining arena, the effects of a policy are unlikely to be anything but weak or diffuse' (1979-80: 611). While agreeing that downstream actors have much to offer in terms of knowledge, commitment and resources that can contribute to successful policy design and execution, we argue that collaboration with the relevant and affected actors can help to spur policy innovation and build the broad political and administrative support that is necessary for ensuring implementation of new and bold solutions to intractable policy problems. Public leaders may also succeed in improving policy design by muddling through and searching for new and better evidence (Lindblom, 1959). However, while over time such attempts to improve policy design through incremental adjustments may significantly increase the chance of successful implementation (Lindblom, 1979), the result is often of a disjointed pattern of policy developments and policy reversals and failure to generate ownership over the revised policy design.

The combination of unmet social demands, rising expectations of citizens, dire fiscal constraints, and an increasing number of wicked problems has recently stimulated interest in public innovation, defined as the development and implementation of new ideas that disrupt the common wisdom and 
habitual practices of public organizations, thus producing a step-change that exceeds the persistent efforts to ensure continuous improvement of known solutions (Osborne and Brown, 2011; Sørensen and Torfing, 2011). In the new and emerging studies of public innovation the primary focus has been on innovation in services, organizations and processes, while there has been limited interest in policy innovation (Vries, Bekkers and Tummers, 2015). The scant regard for policy innovation is regrettable since it is a vital tool for breaking policy deadlocks and cracking intractable problems that can be solved neither by standard solutions nor by increasing public expenditure.

Policy innovation is sometimes fostered top-down by political leaders and administrative policy entrepreneurs who are authorized to define the problem at hand and craft an innovative solution. Top-down policy innovation might be fast and efficient, but the new policy design might suffer from the lack of input from downstream actors and, therefore, might not be as effective in solving the problem as it could have been (Roberts, 2000). In addition, the attempt to circumvent the complex trade-offs between important objectives such as large impact, high quality, low costs and few externalities often requires more innovative 'out-of-the-box' thinking than a few authoritative decisionmakers can muster. Finally, top-down implementation of innovative policy designs that disrupt the work practices of frontline personnel and the entitlements of service users is likely to generate fierce resistance from the downstream actors who have not been involved in the innovation process.

A collaborative approach to policy design can solve all three problems since it can improve the knowledge base, enhance innovation and build a joint ownership (Eggers and Singh, 2009; Sørensen and Torfing, 2011; Hartley, Sørensen and Torfing, 2013; Ansell and Torfing, 2014; Torfing, 2016). Collaboration facilitates a joint exploration of policy problems that allows the 
relevant and affected policy actors to agree on novel ways of defining the problem that both emphasize its urgency and make it solvable. It spurs a constructive use of scientific knowledge in processes of mutual learning and creative problem-solving. Hence, when the participating actors have developed sufficient trust in one another, they will stop using scientific results as political weapons and begin to craft and circulate new ideas and disruptive solutions that are further improved through critical scrutiny, cross-fertilization and integration (Weible and Sabatier, 2009). Collaboration also enables a careful evaluation of alternative solutions through a joint assessment of potential risks and gains that may draw on an experimental testing of prototypes (Bason, 2010). Last but not least, the opportunity for relevant and affected actors to participate in the design of innovative solutions will create a sense of joint commitment to and responsibility for the implementation of the innovative policy design. A joint ownership over innovative policy solutions will help to prevent ignorance, passive resistance and direct sabotage on the part of street-level bureaucrats, and encourage target groups and private stakeholders to explore the possibilities for transforming the logics of the societal subsystems in order to support the realization of shared policy objectives.

Of course, there are many challenges to effective collaboration. Antecedent conditions such as lack of traditions for participation and dialogue, negative experiences with collaborative engagement in the past and unequal distribution of power may make it difficult to bring the relevant and affected parties into a process of fruitful dialogue (Ansell and Gash, 2008). Under some conditions and in policy areas imbued with moral conflicts, collaboration can even accentuate the polarization of stakeholders or lead to vague compromises that merely represent the least-common denominator position (Weible, 2008). In other cases, collaboration may foster a lot of talk, but no action (Lubell, 2009). Nevertheless, the literature suggests that well-designed and effectively-led collaboration can 
succeed in establishing common ground for creative problem-solving (Ansell and Gash, 2012; Torfing, 2016).

Our call for the expansion of collaborative policy design should not make us forget that there is already some deliberation in public hearings and town-hall meetings (Rosenberg, 2007). Many countries have a well-institutionalized system of public hearings convened by parliamentary committees to solicit information, expertise and opinion from public agencies, stakeholders, think tanks, and the general public. Such hearings may allow policymakers to become acquainted with various expert opinions, but they seldom allow politicians to engage in discussions with frontline personnel, user groups and local stakeholders. Citizens are sometimes invited to debate new policies in town-hall meetings, but these meetings are often held so late in the policy process that the room for flexible policy adjustment is very limited and result in considerable frustration among the participants and the policymakers.

Despite these reservations, there are many examples of collaborative policy design in the field of labour market policy (Damgaard and Torfing, 2010), crime prevention (Ercan 2014), educational policy (Roberts and King, 2007), public health care (Scott, 2011), transport policy (Weir, Rongerude and Ansell, 2009) and municipal planning (Sirianni, 2007). The examples demonstrate the value of collaborative policy design for soliciting input to the policy process, enhancing innovation and building ownership for new policies. Some of them also point to the importance of collaboration in the implementation process in order to facilitate flexible adjustments.

\section{Policy Execution through Adaptive Implementation}


So far we have argued that successful policy execution requires that 'policymakers do more than listen to themselves, their in-house analysts, and extant interest groups' (deLeon and deLeon, 2002). Hence, it requires the promotion of what we have termed 'collaborative policy design'. However, implementation of well-crafted policies designed through processes of collaborative innovation cannot be ensured through traditional forms of top-down implementation based on command and control. Successful policy execution requires a continuous collaboration that enables adaptation of the initial policy design to local conditions and emerging problems and opportunities. As such, policy design should be conceived of as an on-going process that flexibly adapts as implementation challenges unfold.

We agree with Berman (1980) who recommends that we move from 'programmed implementation' to 'adaptive implementation' when seeking to implement innovative policy designs in unstable contexts characterized by high levels of uncertainty and conflict. Whereas programmed implementation believes that implementation problems can be made acceptable, if not eliminated, by a careful and explicit pre-programing of implementation procedures, adaptive implementation holds that implementation processes must allow new policy designs and the plans for their implementation to be adapted to unfolding decisions and events (Berman, 1980). In short, we should not aim to 'roll out' new policies like a blanket, but rather 'rub them in' by feeling your way through the specific context and contingencies of implementation.

Benevolent public leaders with good knowledge of operations and strong political support might be able to monitor and adjust the implementation of new policies almost single-handedly, but in most cases they will benefit from multi-actor collaboration when engaging in processes of adaptive implementation. There are at least five different ways that collaboration can facilitate adaptive 
implementation of new policy designs. First of all, collaboration with frontline staff and their representatives may help public leaders responsible for policy implementation to understand the conditions on the ground and how they vary from place to place and between agencies. Such an understanding will facilitate a flexible translation and adoption of new and potentially disruptive policies and permit a carefully calibrated exercise of leadership and deployment of managerial resources. Second, collaboration with frontline staff may help to identify needs in terms of skills, competences and resources and encourage organizational learning and continued experimentation that will improve the production and delivery of new services. Third, collaboration with local stakeholders may not only generate political support and supportive actions from relevant stakeholders, but also solicit constructive feedback on proposed policy solutions that can stimulate policy learning and incremental adjustments (Sabatier and Jenkins-Smith, 1993). Fourth, collaboration with relevant and affected actors provides an early warning system that can help detect problems while they are still small and make swift and jointly agreed responses to new conditions on the group by shortcutting the traditional lines of command (Klijn and Koppenjan, 2004). Finally, collaboration with client and user groups that goes beyond user satisfaction surveys and complaint services may spur co-production of public services and co-creation of new and better solutions (Voorberg, Bekkers and Tummers, 2015).

Adaptive implementation through collaboration with downstream actors, including end users and private stakeholders, is likely to improve policy execution by integrating design and implementation processes. Design and implementation become parts of an integrated process through which the agreements and understandings established during the process of co-design, not to mention the codesigned policies themselves, condition the process of adaptive implementation and the coproduction of outputs. This process also works in the opposite direction. The experiences with 
adaptive implementation and the co-production of outputs can feedback into the subsequent refinement and redesign of policy. The circular movement that connects design and implementation through collaborative feedforward and feedback is shown in Figure 3.

Figure 3: The new collaborative policymaking model

[Please insert figure 3 about here]

\section{Potential Obstacles to Politicians' Participation in Collaborative Policymaking}

The big question is, of course, whether it is possible to motivate the various public and private actors to participate in processes of collaborative policy design and adaptive implementation. Frontline personnel, private stakeholders and target users stand to gain considerable political influence from active participation and this might be a strong motivating factor. By contrast, elected politicians might for a number of reasons be reluctant to embrace the idea of collaborative policy implementation.

First of all, politicians may not be interested in solving complex policy problems by developing new and better policy designs. While some politicians are policy-seeking others are office-seeking and primarily interested in getting re-elected. Paradoxically, inefficient policies that are neither innovative nor tested through a dialogue with downstream actors may be instrumental for achieving that (Winter and Nielsen, 2008). Hence, politicians might opt for symbolic policies that set out some highly ambitious policy objectives while picking policy tools that are completely inadequate, 
but easy to communicate and appealing to popular sentiments. Nevertheless, politicians opting for symbolic policies run the risk that their bluff will be called by policy experts, public managers, interest groups, news reporters and resourceful target groups. Other policy actors will try to hold politicians to account for launching policies that do not properly address the problems at hand and are thus bound to fail.

The second obstacle is that politicians who are accustomed to enjoying authority and responsibility may have reservations about sharing it with others. Politicians tend to see themselves as sovereign decisionmakers who have been given a mandate to rule on behalf of the people rather than with the people. Inviting a broad range of actors that includes more than a few trusted policy advisors and lobbyists to participate in the design of public policies will not appeal to them. Politicians might welcome information, suggestions and support from non-political actors, but horizontal interaction with downstream actors that eventually leads to some kind of joint decisionmaking may appear unattractive. The counterclaim is that politicians who insist that policy design is for politicians only and implementation is someone else's responsibility are likely to lose power in a world of pluricentric governance in which strong interdependencies prevent any single actor from solving complex problems without producing serious externalities, antagonistic conflicts, costly juridical battles and widespread non-compliance (Gray, 1989; Kooiman, 1993). By contrast, politicians aiming to foster new and better policy solutions through collaborative policymaking will benefit from improved policy execution, stronger political support and a shared responsibility for eventual failures.

The third obstacle is that some politicians are driven by strong ideological convictions and therefore tend to be so uncompromising that they are unsuitable for collaborative governance. While 
politicians close to the political centre may be open to policy learning through collaborative interaction with non-political actors with different forms of knowledge, views and ideas, politicians whose political career depends on signaling ideological purity will have problems with participating in collaborative processes that build on deliberation and compromise. However, ideological purism can be self-defeating. Politicians who are not participating in collaborative policymaking are bound to become politically isolated and lose influence and perhaps even voters who despite their admiration for politicians with strong convictions will want to see them engage in dialogue with other parties and actors and contribute to the design and execution of public policy (Hersey, 2014).

A fourth problem is that some politicians are closely tied to particular interest groups that are crucial for securing their re-election. Such ties tend to limit the scope for collaborative policymaking and policy innovation since both political compromises and new disruptive policies might harm the interest that the politicians aim to protect. No agreement will be better than a new and negotiated agreement that rocks the boat. On the other hand, there seem to be clear political limits to non-decisionmaking. Politicians aiming to protect a certain interest will have a hard time preventing other politicians and organized elites from initiating processes of collaborative policy design and adaptive implementation, and they may want to engage in these processes, either to obstruct them or to forge acceptable compromises. Moreover, politicians with clientelist ties face the fact that the interest organizations who feed them campaign donations cannot vote for them. The voters might have other preferences than the lobbyists and might put pressure on the politicians to engage in negotiations about new policy designs that can solve pressing problems.

A final obstacle is the speed of politics in mediatized Western democracies that places enormous pressure on politicians for immediate solutions and swift action (Klijn, 2014). Collaborative 
governance and policy innovation takes time, and if the problem is really urgent, politicians will have problems trying to tell the public that they have just initiated a collaborative process and will soon start some interesting experiments. However, those politicians who fall for the temptation to promise a swift solution that will work tomorrow are likely to lose credibility in the long run when it becomes evident that quick fixes fail to do the trick. Some politicians might rely on their promises being quickly forgotten and washed away by the news stream, but those politicians will eventually be caught up by the fact that they failed to design and implement a proper solution to a pressing policy problem. To actually solve the problem, politicians will benefit from committing themselves to time-consuming collaborative design processes that in the end might speed up the implementation process and deliver results on the ground.

In sum, although there are several obstacles to politicians' embrace of collaborative policymaking, they do not seem insurmountable. Therefore, it is time to begin thinking about the where, when and how of collaborative policymaking. In the last section, we examine some of the scope conditions for collaborative policymaking.

\section{Collaborative Policymaking: Where, When and How}

If collaborative policy design can help to avoid implementation failures, the question becomes under what conditions will such processes thrive? Certain countries and political communities may have political and institutional conditions that either facilitate or hinder collaborative policymaking. Even in places conducive to collaboration, however, there might be certain policy areas that are more amenable to collaborative policymaking than others. Institutional design and management of collaborative policymaking may also influence the opportunities for success. As such, we need to ponder the where, when and how of collaborative policymaking. 
First of all, some types of democracy may be more institutionally inclined towards collaborative policymaking than others. Following Lijphart's (1999) distinction between consensual and majoritarian democracies, it is likely that consensual democracies are more supportive of collaborative policymaking than majoritarian democracies. In the latter, electoral procedure and government formation breed a winner-take-all culture that reduces opportunities for collaboration. By contrast, proportional representation and coalition government tend to cultivate stronger norms and incentives for collaborative policymaking. Countries with strong corporatist legacies are also more likely to encourage collaboration between elected politicians and key stakeholders (Öberg, 2002). By contrast, clientelist political systems or countries with a tendency toward corruption will have a hard time institutionalizing effective arenas for the broad-based collaboration (Piattoni, 2001).

The vertical organization of power and authority in a political system will also impact the conditions for collaboration. In general, collaboration has the best chance of success where local and regional level government has considerable political autonomy and administrative capacity. Proximity between decisionmakers, implementers, and target groups is one factor that can stimulate policy collaboration. Another driver of collaboration is when citizens can see that their participation in collaborative policy formation will actually produce results and influence important decisions that affect their lives. Collaborative policymaking will be most successful when strong local and regional government capacities are matched by a strong and well-organized civil society (Sellers and Kwak, 2011). 
Regardless of institutional context, collaborative policymaking may be contingent upon policy content and situational variables. It goes without saying that convening broad-based participation for collaborative policymaking will be more successful when policy issues are considered salient and urgent. Furthermore, there is a standard argument that issues pertaining to national security and crisis management must be exempted from collaborative processes, either because of the sensitivity of the issues or the time pressure for a response. Even under these conditions, however, collaborative opportunities exist and may be activated (Kettl, 2003). In policy areas with a high degree of ideological polarization, the presence of deep-seated moral, political or ethnic conflicts, or extensive distrust among stakeholders, collaborative policymaking may be challenging (Ansell and Gash 2008). Paradoxically, implementing joint solutions in these policy areas often demands stakeholder collaboration in order to produce robust policy solutions.

After having considered the where and when of collaborative policymaking, we need to also consider the how. Collaborative policymaking calls for the creation of forums for knowledge sharing, sustained dialogue and mutual learning. These forums should enable the formation of networks between interdependent public and private actors. Ideally, the forums for collaborative policymaking should:

- Enable politicians to work together across levels and party lines while focusing on the development of new and better policy solutions

- Ensure interaction between politicians and a broad range of executive civil servants, policy experts from relevant agencies and downstream actors involved in policy implementation

- Involve private stakeholders and target users in co-initiation, co-design and/or coimplementation of public policy 
- Encourage joint deliberation between those actors that can contribute to understanding and defining the problem, advancing creative problem solving, and/or facilitating adaptive implementation

- Provide external input through joint excursions, independent expert reports and comparative studies of solutions in other countries and jurisdictions that can challenge the taken-forgranted-knowledge and stimulate experimentation

- Enable members of the governing parties to play a leading role as sponsors and champions of collaborative policymaking in order to enhance the government's ownership over collaborative policy designs and create political support for adaptive implementation of those policy designs.

These ideal conditions should facilitate collaborative policy design and adaptive implementation, but more research is needed to specify critical factors and deepen our understanding of the institutional design of collaborative policymaking. We need to pay particular attention to exploring the role of political leadership in this process, building for instance on recent attempts to describe strategies of integrative leadership (Crosby and Bryson, 2010).

\section{Conclusion}

This article has returned to a classical problem: the failure to implement and execute public policy. Instead of further pursuing the idea that the new managerialism will finally enable us to close the gap between planned and actual policy outputs and outcomes, we have argued that only by embracing the idea of collaborative policy design and adaptive implementation can we begin to see a possible solution. At a more a practical level we have discussed the obstacles to politicians' 
participation in collaborative policymaking and explored the conditions under which collaborative policymaking can flourish.

Our argument has aimed to create a theoretical rapprochement between well-established implementation theories and new theories of collaborative governance and collaborative innovation. The last two decades have seen an explosion in studies of collaborative governance (Ansell and Gash, 2008; Emerson, Nabatchi, and Balogh, 2012) and more recently it has been suggested that collaborative governance can spur public innovation (Sørensen and Torfing, 2011; Ansell and Torfing, 2014; Torfing, 2016). So far, however, the attempts to connect the expanding theories of collaborative governance and innovation with implementation theory have been few and far between (but see Mayntz, 2016). This is regrettable since the shift from the formal institutions of government to the study of pluricentric forms of governance may help implementation theory to escape the narrow analytical confines created by the chain of command linking office holders and executive managers to middle managers, street-level bureaucrats and service users and instead to adopt a broader and more holistic perspective on policy implementation. The expansion of the range of actors that are relevant for the study of policy design and implementation also heeds the call for a more participatory and democratic perspective on policymaking (deLeon and deLeon, 2002). Indeed, collaborative policymaking is not only capable of enhancing the efficiency and effectiveness of public policies but also the democratic legitimacy of public policymaking (Sørensen and Torfing, 2009). 


\section{Bibliography}

Ansell, C. and Gash, A. (2008), 'Collaborative governance in theory and practice', Journal of Public Administration Research and Theory, 18(4): 543-571.

Ansell, C. and Gash, A. (2012), 'Stewards, mediators, and catalysts', The Innovation Journal, 17(1): Article 7.

Ansell, C. and Torfing, J. (Eds) (2014), Public Innovation through Collaboration and Design, London: Routledge.

Barber, M. (2008), Instruction to Deliver, London: Methuen Publishing.

Bartels, K., Cozzi, G. and Mantovan, N. (2013), 'The Big Society, public expenditure, and volunteering', Public Administration Review, 73(2): 340-351.

Bason, C. (2010), Leading Public Sector Innovation, Bristol: Policy Press.

Berman, P. (1980), 'Thinking about programmed and adaptive implementation', in H. Ingram and D. Mann (Eds), Why Policies Succeed or Fail, Beverly Hills: Sage, 2005-228.

Bobrow, D. and Dzek, J. (1987), Policy Design by Design, Pittsburgh: University of Pittsburgh Press. 
Bommert, B. (2010), 'Collaborative innovation in the public sector', International Public Management Review, 11(1): 15-33.

Box, R. C. (1999), 'Running government like a business', The American Review of Public Administration, 29(1): 19-43.

Braithwaite, V. (1995), 'Games of engagement: Postures within the regulatory community', Law and Policy, 17(3): 225-255.

Burns, J. (2003), Transforming Leadership, New York: Grove Press.

Comfort, L. (1980) 'Evaluation as an instrument for education change', in H. Ingram and D. Mann (Eds), Why Policies Succeed or Fail, Beverly Hills: Sage, 35-57.

Crosby, B., and Bryson, J. (2010), 'Integrative leadership and the creation and maintenance of cross-sector collaborations', The Leadership Quarterly, 21(2): 211-230.

Damgaard, B and Torfing, J. (2010), 'Network governance of active employment policy', Journal of European Social Policy, 20(3): 248-262.

deLeon, P. and deLeon, L. (2002), 'What ever happened to policy implementation', Journal of Public Administration Research and Theory, 12(4): 467-492. 
Deloitte Research (2008), Deloitte Policy Execution Survey. URL: http://ipaciapc.blogspot.dk/search/label/Policy\%20Execution. Retrieved on September 5, 2016.

Eggers, W. and Singh, S. (2009), The Public Innovators Playbook, Washington: Harvard Kennedy School of Government.

Elmore, R. (1979-80), 'Backward mapping', Political Science Quarterly, 94(4): 601-616.

Emerson, K., Nabatchi, T., and Balogh, S. (2012), 'An integrative framework for collaborative governance', Journal of Public Administration Research and Theory, 22(1): 1-29.

Ercan, S. (2014), 'Same problem, different solutions', in A. Gill, C. Strange and K. Roberts (Eds), Honour Killing and Violence, Basingstoke: Palgrave-Macmillan, 199-216.

Goggin, M., Bowman, A., Lester, J. and O'Toole, L. (1990), Implementation Theory and Practices, Glenview: Little Brown.

Gray, B. (1989), Collaborating, San Francisco: Jossey-Bass.

Habermas, J. (1987), The Theory of Communicative Action, Boston: Beacon.

Hall, P. (1982), Great Planning Disasters, Berkeley: University of California Press.

Halpern, D. (2015), Inside the Nudging Unit, London: W. H. Allen. 
Hartley, J., Sørensen, E. and Torfing, J. (2013), 'Collaborative innovation', Public Administration Review, 73(6): 821-830.

Hill, M. and Hill, P. (2014), Implementing Public Policy, London: Sage.

Hirschman, A. (1970), Exit, Voice and Loyalty, Boston: Harvard University Press.

Hogwood, B. and Peters, G. (1985), The Pathology of Policy, Oxford: Oxford University Press.

Hood, C. (1991), ‘A public administration for all seasons?', Public Administration, 69(1): 1-19.

Hood, C. (2010), The Blame Game: Spin, Bureaucracy, and Self-preservation in Government, Princeton: Princeton University Press.

Hoppe, R., van de Graaf, H., and van Dijk, A. (1987), 'Implementation research and policy design', International Review of Administrative Sciences, 53(4): 581-604.

Howlett, M. (2014), 'From the 'old' to the 'new' policy design', Policy Sciences, 47(3): 187-207.

Howlett, M. (2009), 'Governance modes, policy regimes and operational plans', Policy Sciences, 42(1): 73-89. 
Ingram, H. and Schneider, A. (1990), 'Improving implementation through framing smarter statutes', Journal of Public Policy, 10(1): 67-88.

Kettl, D. (2003), 'Contingent coordination practical and theoretical puzzles for homeland security', The American Review of Public Administration, 33(3): 253-277.

Kingdon, J. (1984), Agendas, Alternatives, and Public Policies, Boston: Little Brown.

Klijn, E. and Koppenjan, J. (2004), Managing Uncertainties in Networks, London: Routledge.

Klijn, E.-H. (2014), 'Political leadership in networks', in Rhodes, R. and 't Hart, P. (Eds), The Oxford Handbook of Political Leadership, Oxford: Oxford University Press, 403-418.

Kooiman, J. (Ed.) (1993), Modern Governance, London: Sage.

Kotter, J. (1999), What Leaders Really Do, Boston: Harvard Business Review Books.

Le Grant, J. (2011), 'Quasi-markets vs. state provision of public services', Public Reason, 3(2): 8089.

Light, P. (2015), 'Vision + action = faithful execution', Issue Paper, https://www.volckeralliance.org/sites/default/files/attachments/Vision $\% 20 \% 2 \mathrm{~B} \% 20$ Action $\% 20$ \%20The\%20Volcker\%20Alliance.pdf. Retrieved on September 5, 2016. 
Lijphart, A. (1999), Patterns of Democracy, New Haven: Yale University Press.

Lindblom, C. E. (1959), 'The science of "muddling through"”, Public Administration Review, 19(2): 79-88.

Lindblom, C. E. (1979), 'Still muddling, not yet through', Public Administration Review, 39(6): 517-526.

Linder, S. and Peters, G. (1987), ‘A design perspective on policy implementation', Review of Policy Research, 6(3): 459-475.

Lipsky, M. (1980), Street-level Bureaucracy, New York: Russell Sage Foundation.

Lubell, M. (2004), 'Collaborative environmental institutions', Journal of Policy Analysis and Management, 23(3): 549-573.

Macmillan, P. and Cain, T. (2010), Closing the Gap, Vancouver: Deloitte.

Majone, G. and Wildavsky, A. (1979), 'Implementation as evolution', in J. Pressman and A. Wildavsky (Eds), Implementation, Berkeley: University of California Press.

Matland, R. (1995), 'Synthesizing the implementation literature', Journal of Public Administration Research and Theory, 5(2): 145-174. 
May, P. (2012), 'Policy design and implementation', in G. Peters and J. Pierre (Eds), Handbook of Public Administration, Thousand Oaks: Sage, 279-291.

May, P. (2015), 'Implementation failures revisited', Public Policy and Administration, 30(3-4): 277-299.

Mayntz, R. (1993), 'Governing failure and the problem of governability’, in J. Kooiman (Ed.), Modern Governance, London: Sage, 9-20.

Mayntz, R. (2016), 'Steering', in C. Ansell and J. Torfing (Eds), Handbook on Theories of Governance, Cheltenham: Edward Elgar, 259-266.

Meier, K. and Boyte, J. (2007), Politics and the Bureaucracy, Belmont: Wadsworth Publisher.

Moynihan, D. (2008), The Dynamics of Performance Management, Washington: Georgetown University Press.

Öberg, P. (2002), 'Does administrative corporatism promote trust and deliberation?', Governance, 15(4): 455-475.

Osborne, D. and Gaebler, T. (1993), Re-inventing Government, Reading: Addison-Wesley.

Osborne, S. and Brown, L. (2011), 'Innovation, public policy and public services delivery in the UK', Public Administration, 89(4): 1335-1350. 
Page, S. (2010), 'Integrative leadership for collaborative governance', The Leadership Quarterly, 21(2): 246-263.

Parry, K. and Bryman, A. (2006), 'Leadership in organizations', in S. Clegg, C. Hardy, T. Lawrence and W. Nord (Eds), The Sage Handbook of Organization Studies, London: Sage, 447-468.

Piattoni, S. (2001), Clientelism, Interests, and Democratic Representation, Cambridge: Cambridge University Press.

Pierre, J. and Røiseland, A. (2016), 'Exit and voice in local government reconsidered', Public Administration. DOI: 10.1111/padm.12258

Pressman, J. and Wildawsky, A. (1973), Implementation, San Francisco: University of California Press.

Roberts, N. (2000), 'Wicked problems and network approaches to resolution', International Public Management Review, 1(1): 1-19.

Roberts, N. and King, P. (1996), Transforming Public Policy, San Francisco: Jossey-Bass.

Rosenberg, S. (Ed.) (2007), Deliberation, Participation and Democracy, Basingstoke: PalgraveMacmillan. 
Sabatier, P. (1986), 'Top-down and bottom-up approaches to implementation research', Journal of Public Policy, 6(1): 21-48.

Sabatier, P. and Jenkins-Smith, H. (Eds) (1993), Policy Change and Learning, San Francisco: Westview Press.

Schneider, A. and Ingram, H. (1988), ‘Systematically pinching ideas', Journal of Public Policy, 8(1): 61-80.

Schneider, A. and Ingram, H. (1990), 'Policy design: Elements, premises and strategies', in S. S. Nagel (Ed.), Policy Theory and Policy Evaluation, Westport: Greenwood, 77-102.

Scott, C. (2011), 'A case study in collaborative governance', Conflict Resolution Quarterly, 28(4): 441-463.

Sellers, J. and Kwak, S. (2011), 'State and society in local governance', International Journal of Urban and Regional Research, 35(3): 620-643.

Simon, H. (1957), Models of Man, New York: Wiley.

Sirianni, C. (2007), 'Neighborhood planning as collaborative democratic design', Journal of the American Planning Association, 73(4): 373-387.

Sørensen, E. (1997), 'Democracy and empowerment', Public Administration, 75(3): 553-567. 
Sørensen, E. and Torfing, J. (2011), 'Enhancing collaborative innovation in the public sector', Administration and Society, 43(8): 842-868.

Sørensen, E. and Triantafillou, P. (Eds) (2009), The Politics of Self-Governance, London: Ashgate.

Torfing, J. (2016), Collaborative Innovation in the Public Sector, Washington, DC: Georgetown University Press.

Voorberg, W., Bekkers, V., and Tummers, L. (2015), 'A systematic review of co-creation and coproduction', Public Management Review, 17(9): 1333-1357.

Teubner, G. and Willke, H. (1984), 'Kontext und Autonomie', Zeitschrift für Rechtssoziologie, 6: 435.

Torfing, J. (2016), Collaborative Innovation in the Public Sector, Washington: Georgetown University Press.

Volcker, P. (2014), 'Vision without execution is hallucination', Public Administration Review, 74(4): 439-441.

Vries, H., Bekkers, V. and Tummers, L. (2015), 'Innovation in the public sector', Public Administration, 94(1): 146-166. 
Weaver, K. (2010), ‘But will it work?’, Issues in Government Studies, 32: 1-17.

Weible, C. (2008), 'Caught in a maelstrom', Coastal Management, 36(4): 350-373.

Weible, C. and Sabatier, P. (2009), 'Coalitions, science and belief change', The Policy Studies Journal, 37(2): 195-212.

Weir, M., Rongerude, J. and Ansell, C. (2009), 'Collaboration is not enough', Urban Affairs Review, 44(4): 455-489.

Winter, S. and Nielsen, V. (2008), Implementering af politik, Aarhus: Academica.

Figure 1: $\quad$ Sources of implementation failure in classical implementation theories

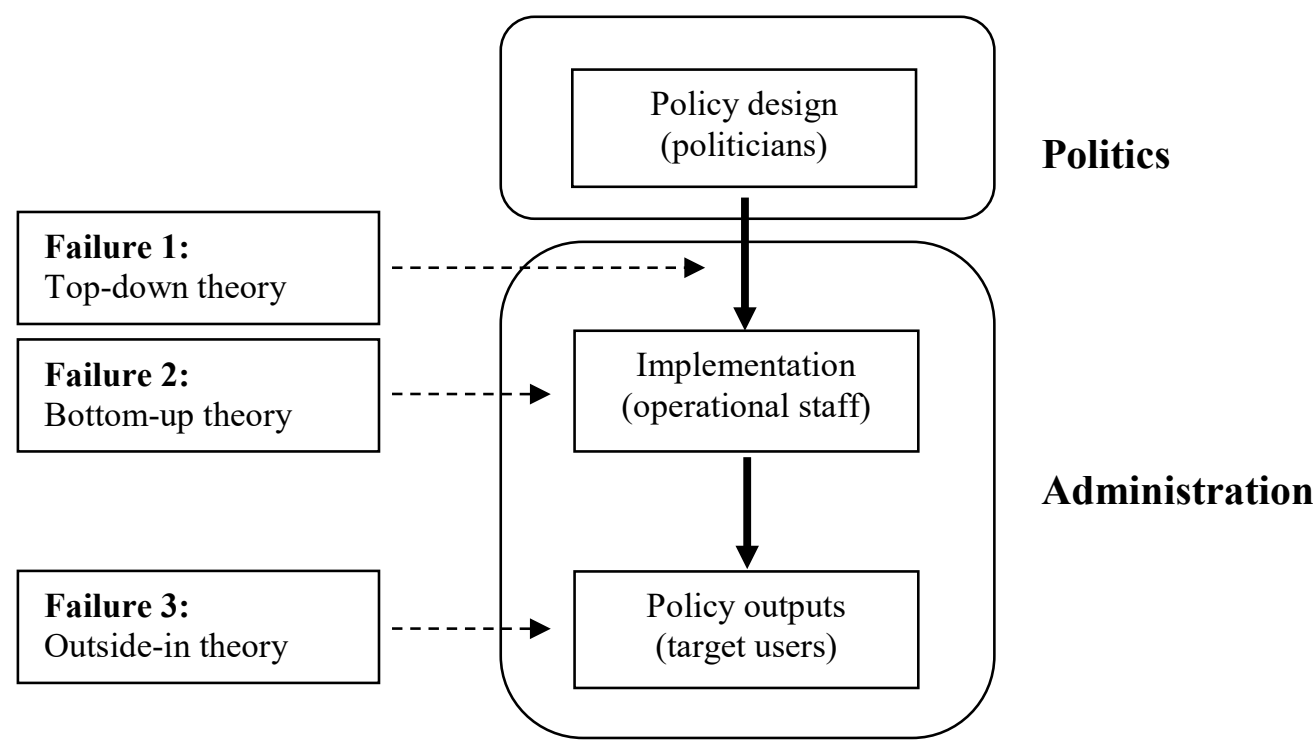


Figure 2: $\quad$ Four sources of policy execution failure

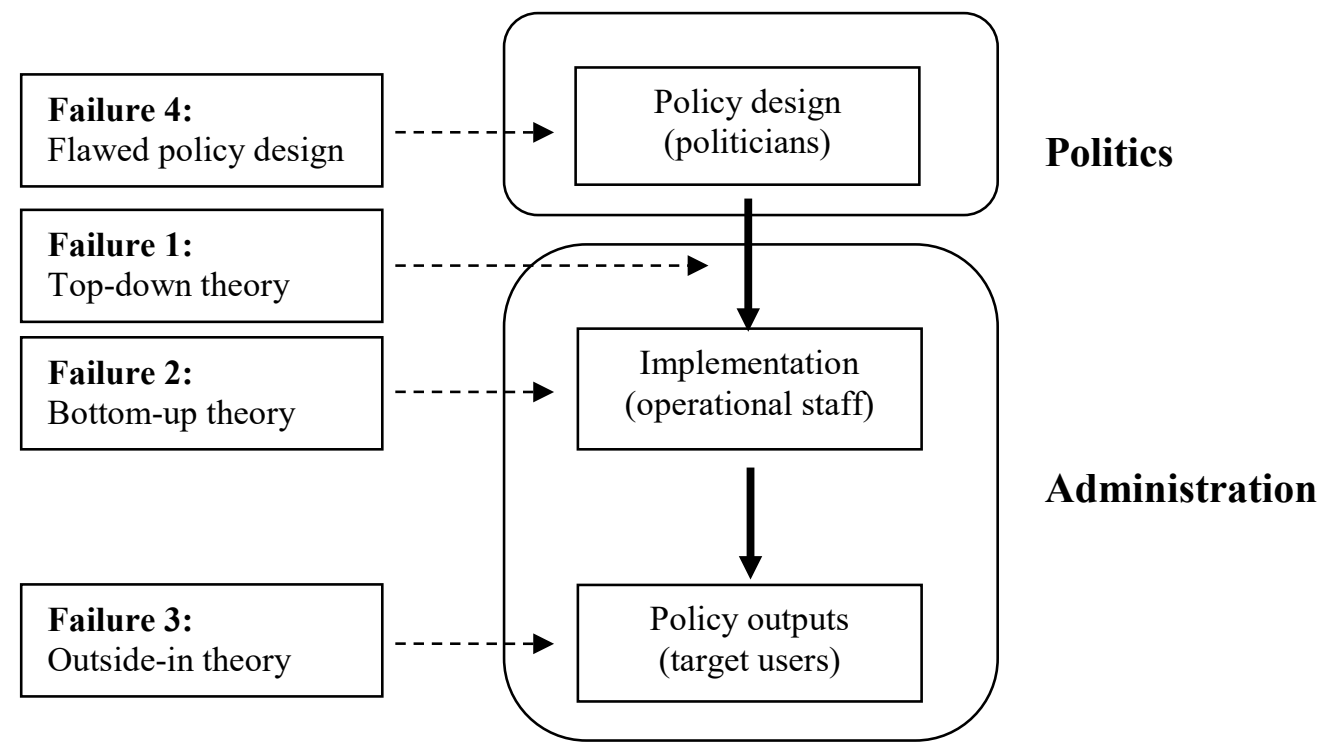


Figure 3: The new collaborative policymaking model

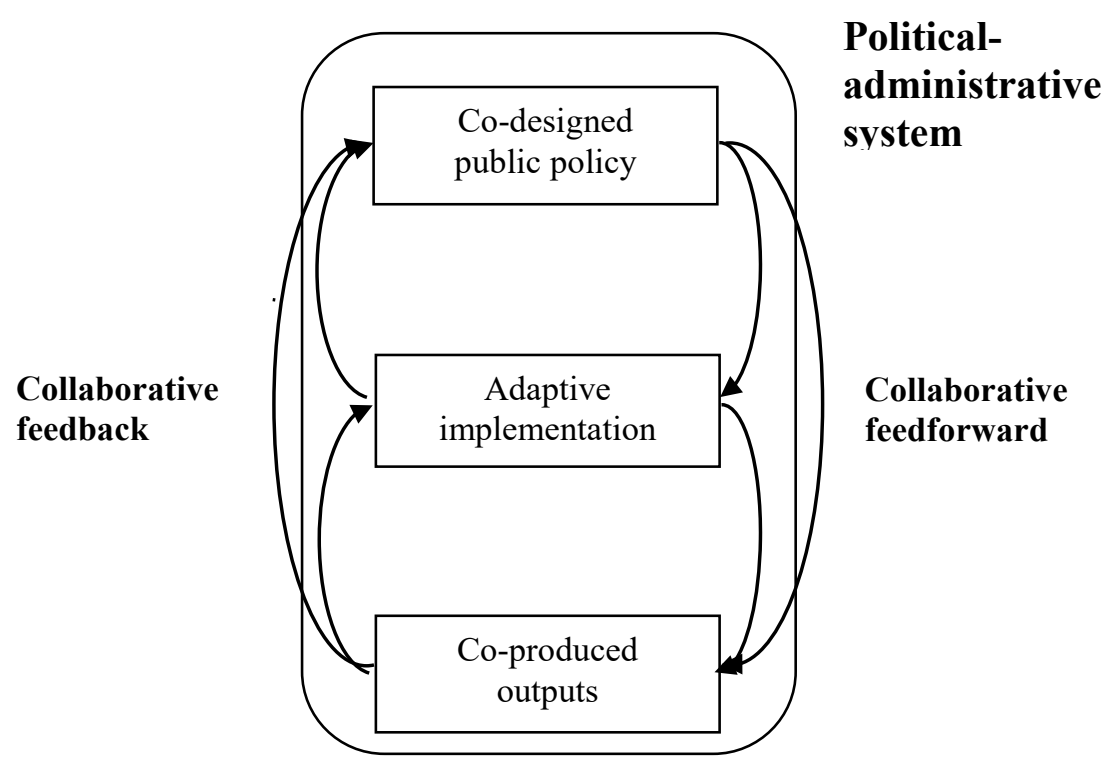

